\title{
Growth of Higher Education in India during the Period 1950- 2005
}

\author{
Dr. Heena Upadhyaya \\ Department of Business Economics, Faculty of Commerce \\ The M.S. University of Baroda, Vadodara, Gujarat, India
}

\begin{abstract}
Education influences Economic Development directly and also indirectly. The direct impact is through productivity, employment, composition of the labour force, division of labour, mobility of labour, and other such factors. The indirect impact is through savings, limiting family size, inculcating right attitudes and skills, and by removing obstacles to social change and progress. It facilitates attitudinal changes for modernization and social transformation. This study investigates the growth of higher education in India during the period 1950 to 2005. The objective of this study is analyzed using the year wise growth rate formula. The result shows that the there is satisfactory growth of higher education in India During study period.
\end{abstract}

Keywords: Education influences, Economic Development, Productivity, Employment, Modernization

\section{Introduction}

Developing countries and developed ones have rapid economic development as the primary objective. Human beings play a crucial role in this development. Gerald M, Meir has aptly remarked: "The key to development is human being and his (her) abilities, values and attitudes must be changed in order to accelerate the process of development" (Meir G.M., 1975). Education plays a key role in this process. Theoretical and empirical researches have substantiated the fact that investment in human capital formation of a country plays a fundamental role in improving the efficiency and productivity of human beings, and through them the various factors that complement and supplement the production process. This investment in people, especially through the medium of education has attracted the attention of economists across the world. A properly planned education system contributes significantly to the growth and economic development of a country (Agrawal P., 1982). The modern university system in India came into existence during British rule. However, the seeds of higher learning have its deep rooted origin since the vedic times in the form of gurukuls and ashrams.

In India, during the British rule, the first three universities were set up in 1857 and the thrust of development was mainly on liberal Arts education. Growth was modest with 18 universities established over a period of 90 years. Most of these followed the model of the three leading universities at Bombay, Calcutta and madras. At the time of independence, there were 20 universities and about 500 colleges, with an enrolment of less than 150,000. Presently, the Indian system of higher education is one of the largest in the world (Tilak JBG, 2007).

\section{Review of literature}

Lakdawala D.T. and Shah K.R. (1978) studied the funding pattern of education in Gujarat state during 1960-61 to 1969-70. The study examined the unit cost in colleges and their economic and optimum size. The study proposed policy actions and revision of funding pattern in higher education.

Tilak J.B.G. and Varghese N.V. (1991), in their study entitled "Financing of Education in India," analyzed various aspects of public financing of education in India, particularly the centre-state partnership in deciding the total amount of resource allocation to education, its distribution by levels of education and interstate differences. The study also discussed possible alternative sources of financing education. The study argued that fee is an important source of additional financing for education in India. Majority of the resources spent on education come from government sources, which has little possibility of any further increase. Therefore, optimum utilization of existing resources and mobilization of additional resources becomes very important for financing education in the coming years. Another important aspect is the devolution of financial and other authority between the state and districts for evolving policies on financing education in India in the coming years.

OECD conducted an Economic Survey of India (OECD, 2007). It suggested that there is an urgent need to improve education in India. The study found that there are marked differences in educational attainment across gender and social backgrounds. However, higher enrolment is just a first step to better outcomes. More needs to be done to raise the quality of education, including providing stronger incentives for teachers to work and improving both the attendance and completion rates of students and teachers' training. Educational reforms at the state-level and in OECD countries suggest that decentralisation helps to raise efficiency and should be encouraged. 
Agarwal Pawan (2006) in his paper on 'Higher Education in India: The Need for Change' lays down an agenda for reforms in the higher education sector in India. The paper relates to the growth of higher education in India in relation to the changing funding pattern and suggests ways to ensure that higher education remains both affordable and accessible to all. The author emphasizes the need for greater adaptability in the higher education system so that it continues to provide the needed skills and trained workforce to the economy as it integrates with the world economy. The author also suggests policy measures required to promote, sustain, and enhance world-class research. Considering the weaknesses in the prevailing regulatory and quality assurance environment. The paper provides a roadmap for reforms towards improved accountability of the system.

Mukherjee A.N. in his study "Public Expenditure on Education: A Review of Selected Issues and Evidence" (2007) discusses the role of education in economic development which has been recognized in mainstream economic literature. Divergence between the private and social rate of return from education is the rationale for intervention by the state in ensuring equity in opportunity across the population. The 'New Growth Theories' predict that higher levels of schooling and better quality of workforce will lead to an increase in the growth rate, further strengthening the case for public expenditure on education. The outcome of such research has implications for the financing of education.

However, the effectiveness and efficiency of resource allocation by the government has generated considerable debate, both from ideological and technical points of view. It is widely acknowledged that there is a large scope for improvement in both the level and the quality of publicly funded education. New institutional arrangements are being designed to address the deficiencies in incentives and monitoring, thereby improving quality.

\section{Objective}

The specific objective of this study is to examine the growth of Higher Education in India During the period 1950-2005

Hypothesis: There is no significance growth of higher Education in India during the Period 1950-2005.

\section{Data Source and Research Methodology}

The study used secondary data available in published sources. The time series data on Institutions, Enrolment and Teachers in Higher Education in India were compiled from Various Report Published by the Ministry of Human Resource Development Department of Higher Education New Delhi. Year wise Growth Rate calculated by Following Formula:

Growth Rate $=($ New Value-Old Value/ Old Value $) * 100$

\section{Empirical Results}

Table 1

Growth of Institutions, Enrolment and Teachers in Higher Education in India

\begin{tabular}{|c|c|c|c|c|}
\hline Year & Universities * & Colleges & Enrolment ('000) & Teachers ('000) \\
\hline $1950-51$ & 28 & 578 & 174 & 24 \\
\hline $1960-61$ & 45 & 1819 & 557 & 62 \\
\hline $1970-71$ & 93 & 3227 & 1956 & 190 \\
\hline $1980-81$ & 123 & 4738 & 2752 & 244 \\
\hline $1990-91$ & 184 & 5748 & 4925 & 271 \\
\hline $2004-05$ & 348 & 17625 & 10481 & 472 \\
\hline
\end{tabular}

Source: Ministry of Human Resource Development Department of Higher Education

Note: * Universities include central, state, private and deemed to be universities as also institutions of national importance established both by the central and state Governments.

During 1950-51 to 2004-05, the number of universities has increased from 28 to 418, and the number of colleges from 578 to 17,635. During the same period, enrolment in higher education has also increased from 0.174 million to 10.48 million. The number of teachers has also gone up from around 24,000 in 1950-51, to 4,72,000 in 2004-05. The expansion of higher education after independence was higher during the decades of 1950s and 1960s. This may be because of the growing demand for higher education during this period which 
was a global phenomenon. The growth of such institutions was comparatively slow during the 1970s and 1980s. However, during 1990s and onwards, the expansion of higher education system has regained momentum.

Table 2

Growth of Higher Education in India (CAGR \%)

\begin{tabular}{|l|c|c|c|c|}
\hline Year & Universities & Colleges & Enrolment & Teachers \\
\hline $1950-51$ to $1960-61$ & 4.86 & 12.15 & 12.34 & 9.96 \\
\hline $1960-61$ to $1970-71$ & 7.53 & 5.90 & 13.38 & 11.85 \\
\hline $1970-71$ to $1980-81$ & 2.84 & 3.92 & 3.47 & 2.53 \\
\hline $1980-81$ to $1990-91$ & 4.11 & 1.95 & 5.99 & 1.06 \\
\hline $1990-91$ to $2000-01$ & 3.75 & 6.85 & 5.48 & 3.84 \\
\hline $2000-01$ to $2004-05$ & 11.22 & 12.14 & 5.69 & 4.55 \\
\hline
\end{tabular}

\section{Source: Author's own calculation}

During the year 1950-51 to 1960-61, the number of universities has grown at a compound annual growth rate (CAGR) of $4.86 \%$ per annum, while colleges at a rate of $12.15 \%$ per annum. During $1970 \mathrm{~s}$, 1980s and 1990s, the rate of growth was relatively low compared to the earlier period on all parameters. This has increased considerably during the period 2000 and then after when the compounded annual growth rate of universities has been more than $11 \%$ per annum and that of students' enrolment and teachers being around $5 \%$ per annum. In the present times, as shown in table 1.05, as of 2006, the number of institutions has grown considerably during the period 2001 and onwards. This may be because of the efforts made by the government in promoting the establishment of institutions of higher education etc.

Table 3

Number of Universities and Other Academic Institutions till 2006

\begin{tabular}{|c|c|c|c|c|c|}
\hline Academic Institutions & \multicolumn{5}{|c|}{ Total number up to: } \\
\hline $\begin{array}{l}\text { Type of Universities and other Academic Institutions } \\
\text { till } 2006\end{array}$ & 1947 & 1966 & 1980 & 1993 & 2006 \\
\hline Central Universities & 3 & 5 & 8 & 10 & 18 \\
\hline Institutions recognized as 'Deemed Universities' & 5 & 11 & 12 & 30 & 95 \\
\hline Institutions of National Importance & 2 & 9 & 9 & 10 & 13 \\
\hline State General Universities & 18 & 56 & 81 & 112 & 176 \\
\hline State Agriculture Universities & --- & 6 & 20 & 25 & 40 \\
\hline Total & 28 & 87 & 130 & 187 & 342 \\
\hline
\end{tabular}

Source: Ministry of Human Resource Development Department of Higher Education

As is shown in the table 3 there has been a sharp increase in the number of state universities and institutions recognized as "deemed to be universities during the recent times" and the total number of universities and other institutions has increased from 28 at the time of independence which has risen to 342 during 2006.

\section{Conclusion}

Nevertheless, in spite of these impressive figures, India lags far behind the developed countries with a population of 100 crores the country has only 417 universities. In contrast to this, Japan with a population of 12.7 crores has 684 universities and The USA, with a population of 27.6 crores, has 2364 universities. Germany has 330 universities with population of 8.2 crores. The average size of Indian higher education institution in terms of enrolment is much smaller compared to that of Europe, US and China. 


\section{References}

[1] Agarwal Pawan (2006), 'Higher Education in India: The Need for www.icrier.org/pdf/icrier_wp180_Higher_Educaion_in_India_pdf (viewed as on 12-1-2009)

[2] Agrawal, P. (1982) 'Financing of Higher Education in India', Ganga Kaveri Publishing House, Varanasi.

[3] Lakdawala D. T. and Shah K. R. (1978) "funding pattern of education in Gujarat state during 1960-61 to 1969-70".Optimum Utilization of Educational Expenditure in Gujarat, Ahmedabad, sardar Patel Research Institute

[4] Meier G.M (1975), 'Leading Issues in Economic Development', Oxford University Press, London.

[5] Mukherjee A (2007), 'Public Expenditure on Education: A Review of Selected Issues and Evidence', Working paper from financing Human Development paper 1, National Institute of Public Finance and Policy.

[6] OECD (2007) www.oecd.org/dataoecd (viewed as on 12-1-2009)

[7] Tilak J.B.G and Varghese N.V. (1991) "Financing of Education in India', International Institute of educational Planning, Anybool ltd. United Kingdom

[8] Tilak, J.B.G. (2007), 'Student loan and Financing of Higher Education in India', Journal of Educational Planning and Administration, July, Volume XXI, No. 3. 